\title{
Supramolecular Chemistry of Selective Anion Recognition for Anions of Environmental Relevance
}

\section{FY 2005 Annual Report, Environmental Management Science Program, Project \#90301 Results at Oak Ridge National Laboratory}

Bruce A. Moyer (Co-PI), Debra A. Bostick, Christopher J. Fowler, Hyun-Ah Kang, Alexandre Ruas, Lætitia H. Delmau, and Tamara J. Haverlock

Chemical Sciences Division, Oak Ridge National Laboratory, P.O. Box 2008, Oak Ridge, TN 37830-6119

José M. Llinares, Md. Alamgir Hossain, S. O. Kang, and Kristin Bowman-James (Lead PI) Department of Chemistry, University of Kansas, 1251 Wescoe Hall Drive, Lawrence, Kansas $66045-7582$

James A. Shriver, Manuel Marquez, and Jonathan L. Sessler (Co-PI) Department of Chemistry and Biochemistry, University of Texas, 1 University Station A5300, Austin, Texas 78712-0165

Sept. 22, 2005

This research was sponsored by the Environmental Management Science Program of the Office of Science, U. S. Department of Energy, under a) contract no. DE-AC05-00OR22725 with Oak Ridge National Laboratory, managed and operated by UT-Battelle, LLC; Grant Nos. DE-FG96ER62307 and DE-FG02-04ER63745 to the University of Kansas; and c) Grant DE-FG0204ER63741 to the University of Texas, Austin. Any opinions, findings, conclusions, or recommendations expressed herein are those of the authors and do not necessarily reflect the views of DOE. Any opinions, findings, conclusions, or recommendations expressed herein are those of the authors and do not necessarily reflect the views of DOE. 


\section{ANNUAL PROGRESS REPORT}

\section{U.S. Department of Energy \\ Supramolecular Chemistry of Selective Anion Recognition for Anions of Environmental Relevance Results at Oak Ridge National Laboratory}

Lead Principal Investigator: Prof. Kristin Bowman-James, Department of Chemistry, University of Kansas, 1251 Wescoe Hall Drive, Lawrence, Kansas 66045-7582. Phone: 785-864-3669. Fax: 785-864-5396. E-mail: kbjames@ku.edu

Co-Principal Investigator: Bruce A. Moyer, Oak Ridge National Laboratory, Bldg. 4500S, MS 6119, P.O. Box 2008, Oak Ridge, TN 37831-6119. Phone: 865-574-6718. Fax: 865-574-4939. Email:moyerba@ornl.gov

Co-Principal Investigator: Lætitia H. Delmau, Oak Ridge National Laboratory, Bldg. 4500S, MS 6119, P.O. Box 2008, Oak Ridge, TN 37831-6119. Phone: 865-576-2093. Fax: 865-574-4939. Email: delmaulh@ornl.gov

Co-Principal Investigator: Prof. Jonathan L. Sessler, Department of Chemistry and Biochemistry, University of Texas, 1 University Station - A5300, Austin, Texas 78712-0165. Phone: 512-4715009. Fax: 512-471-7550. E-mail: sessler@mail.utexas.edu

Statistics since start of renewal Oct. 1, 2003: (Oak Ridge National Laboratory only)

Number of undergraduate students: 0

Number of graduate students: 0

Number of postdocs: 2

EMSP Project: $\quad$ \#90301 (formerly \#74019)

Contract \#: $\quad$ DE-AC05-00OR22725 (ORNL, FWP No. ERKP600)

DE-FG-96ER62307 and DE-FG02-04ER63745 (KU)

DE-FG02-04ER63741 (UT, Austin)

Project Duration (Renewal): $\quad$ Oct. 1, 2004 - Sept. 30, 2007

ORNL Program Officer: $\quad$ Gary K. Jacobs, Oak Ridge National Laboratory, Oak Ridge, TN 37831-6119, P.O. Box 2008, Bldg. 4500S. Phone: (865) 574-

7374. Fax: (865) 574-7287. E-mail: jacobsgk@,ornl.gov . 


\section{Summary}

The major thrust of this project led by the University of Kansas (Prof. Kristin BowmanJones) entails the exploration of the principles of recognition and separation of sulfate by the design, synthesis, and testing of novel sulfate extractants. A key science need for the cleanup of tank wastes at Hanford has been identified in developing methods to separate those bulk waste components that have low solubilities in borosilicate glass. Sulfate has been identified as a particularly difficult and expensive problem in that its concentration in the waste is relatively high, its solubility in glass is especially low, and it interferes with the performance of both vitrification equipment and the glass waste form. The new extractants will be synthesized by the University of Kansas and the University of Texas, Austin. Oak Ridge National Laboratory $(\mathrm{ORNL})$ is subjecting the new extractants to experiments that will determine their properties and effectiveness in separating sulfate from the major competing anions in the waste, especially nitrate. Such experiments will entail primarily liquid-liquid extraction. Current efforts focus on exciting new systems in which the anion receptors act as synergists for anion exchange.

\section{Research Objectives}

Purpose. The goal of this project is to use emerging principles of anion recognition to develop highly selective extractants that are capable of removing sulfate anion from nuclear wastes prior to vitrification. Sulfate separation offers potential value in the cleanup of the Hanford tanks in that sulfate interferes with making glass. One option for dealing with this potentially costly problem is to remove the sulfate from the waste. However, various technologies for doing so either have performed poorly in tests or have undesirable attributes justifying investment in basic research. Promising approaches to overcoming these limitations are emerging in the young science of designing receptors for anion binding and extraction. The approach proposed here combines the expertise of three research groups, two of which are accomplished in the area of selective anion-receptor design (Kristin Bowman-James at Univ. of Kansas and Jonathan Sessler at Univ. of Texas, Austin) and one that is noted for its successful development of substrate-specific liquid-liquid extraction systems (Bruce Moyer at ORNL). The proposed work is thus expected to lead to new, state-of-the-art extractants that will not only provide important insights into the fundamental determinants of anion recognition but also allow the specific, extraction-based removal of sulfate anion from nitrate-rich environments, including ones simulating those found at the Hanford and Savannah River nuclear waste sites.

This work builds on an exciting body of previous accomplishment. For instance, since the time of the last competitive renewal, synthetic sulfate-selective anion-binding agents have been produced and are among the first reports of selective receptors for sulfate. Further, simple, structure-based methods for modifying the intrinsic anion selectivity of a given class of anion receptor have been developed. Finally, the first system capable of extracting sulfate anion from an aqueous solution containing 100-fold greater concentration of the competing anion, nitrate, was discovered. This latter result was achieved by a novel synergistic enhancement of liquidliquid anion exchange ( $>100$-fold for sulfate) and is considered to represent the key, proof-of-

principle step forward. This success thus has us very excited about the prospects for further progress. 
This project addresses the OBER long-term environmental-remediation goal "Develop science-based solutions for cleanup and long-term monitoring of Department of Energy (DOE) contaminated sites." It is clearly aimed toward development of a science-based solution to tankwaste cleanup.

EM needs benefited by this research. Certain anions, especially oxoanions, have been prominent as contaminants (e.g., pertechnetate), troublesome species (e.g., sulfate, chromate, and phosphate), or ubiquitous matrix components that can pollute (e.g., nitrate) in environmental or waste treatment processes in the US Department of Energy (USDOE) complex. In the first phase of this project, we approached the topic of anion recognition and separation broadly targeting such oxoanions. In the past several years, however, the presence of sulfate in tank waste has risen to be a critical concern in meeting the objectives of Mission Acceleration at Hanford, as it is a key determinant of the volume of expensive low-activity-waste (LAW) glass that will be produced from the waste. In view of the urgency of this need, we have undertaken now to focus our research on the problem of sulfate binding and separation.

The sulfate problem has been spelled out in detail in various needs statements pertaining to the Hanford site, as previously issued by the USDOE Office of Environmental Management. In particular, EM Need RL-WT081 recognized sulfate management in low activity waste via pretreatment, vitrification, and off-gas approaches as having important beneficial consequences. The Hanford Site Need RL-WT-1019 described the need for, and benefits of, sulfate mitigation, without which as much as $20 \%$ more glass would have to be produced. Such a penalty represents a serious obstacle to the Mission Acceleration Initiative, which seeks to reduce the time to clean up the Hanford tanks by 20 years and to reduce the cost of the cleanup by $\$ 20 \mathrm{~B}$. Sulfate is in fact present in the tank wastes at several USDOE sites, including the Savannah River Site and the Idaho National Laboratory (INL), as well as Hanford. It is only a particularly acute issue at Hanford, because of the unique requirement there that specifies vitrification of the LAW that results from radionuclide removal from the retrieved tank waste. It is known that sulfate has a low solubility (typically $<1 \%$ ) in borosilicate glasses and at elevated levels will migrate to the top of the melt as a separate phase. Such phase separation has been documented in numerous studies of nuclear-waste vitrification. Although the cited studies focus on Hanford waste vitrification, sulfate phase separation has been observed and is considered a potential issue, for example, in studies of vitrification of the sodium bearing waste at the INL. Sulfate phaseseparation problems compromise both the vitrification process and the integrity of the final waste form. Specific processing problems include inhibition of melting rate, short-circuiting of the electrodes, corrosion of the melter, electrodes, and off-gas equipment. In addition, the final glass product containing high sulfate levels can exhibit increased leach rates, a waste-form performance issue.

In view of the above problems associated with sulfate in vitrification of the Hanford LAW, recent studies have with limited success been directed toward identifying technologies for removal of the sulfate prior to vitrification. Suggested strategies have included evaporative crystallization of burkeite $\left[\mathrm{Na}_{6}\left(\mathrm{SO}_{4}\right)_{2} \mathrm{CO}_{3}\right]$, which in tests did not prove sufficiently selective. Precipitating agents, such as barium or strontium nitrate, can effect sulfate removal, though with selectivity and secondary-waste issues. Ion exchange proved ineffective. Still, planning in the Mission Acceleration Initiative included provision for sulfate removal to reduce the volume of immobilized LAW and corresponding costs. Since options for removing the sulfate from the highly alkaline waste have been unattractive, the suggested approach involves acidification of the salt waste and precipitation of strontium sulfate. With options so clearly limited, the need for 
basic research to provide new alternatives seems obvious to us. Such alternatives might avoid waste acidification, for example, or they might prove more efficient.

Approach. We propose an extractive approach. From a generic technology standpoint, solvent extraction has been a venerable technique in nuclear separations industry and represents a viable high-throughput technique. Although most applications have involved nitric acid aqueous phases, treatment of alkaline nuclear waste by solvent extraction has recently been demonstrated in the case of the Caustic-Side Solvent Extraction (CSSX) process for cesium removal from the Savannah River Site tank waste. The CSSX process uses a calixarene-crown ether as a cesium extractant and has been selected for implementation in the Savannah River Site Salt Waste Processing Facility, now in privatized design. Crown ethers have also found application in the SREX process for strontium separation from acidic nuclear waste. Thus, precedent exists for applications for both acid and alkaline media using designed ion receptors. That anion receptors will work for specific anion extraction applications in nuclear or hydrometallurgical applications seems an obvious expectation, but to our knowledge, no such precedent so far exists.

During the last funding period, we have made significant strides in both receptor design as well as in separation strategy. This project seeks to exploit these advances toward a greater understanding of sulfate binding and transport as relevant to tank waste media, whether acidic or alkaline. The firm foundation of results is ultimately expected to provide the basis for the design of a viable, selective sulfate extraction system for on-site use, thereby reducing the number of LAW glass canisters required for storage with a significant reduction in cost. In this manner, this proposal directly supports the Mission Acceleration Initiative at Hanford.

While it is clear from a growing literature and from our own results that multiple strong hydrogen-bond donor groups must be organized to act in concert to effect sulfate extraction, an in-depth understanding of all of the contributing factors and their interrelationships to selective sulfate-receptor binding is still lacking. Thus, a number of critical questions remain:

- It is unclear what impact structural and electronic factors have on preorganization and topological complementarity, and consequently on binding affinity and selectivity.

- It is also not completely resolved whether it is best to employ neutral receptors as synergists for anion exchange (as we have so far demonstrated) or so-called dual-host systems for co-extraction of sulfate and cation, either sodium or hydrogen ion. In synergized anion exchange, a neutral anion receptor is mixed with a classical lipophilic quaternary ammonium extractant. In a dual-host approach, the neutral anion receptor is mixed with a neutral cation receptor (e.g., crown ether). Which approach to use is essentially a question of how best to achieve charge balance in sulfate transport.

- The necessity of charge balance further raises the interesting design question as to whether one gains an advantage by functionalizing a neutral anion receptor with either a quaternary ammonium group or neutral crown ether so that charge-complementarity is incorporated into the sulfate receptor itself.

- Candidate systems must also meet the critical test of reversibility, that is, the ability to release sulfate and regenerate the extractant(s) for reuse, and this aspect is still awaiting exploration.

- Secondary extractant-design questions are also important, such as how to ensure that the extractants and their complexes are sufficiently lipophilic and soluble in the organic solvent matrix without interfering with sulfate binding.

To address the questions outlined above, a range of macrocyclic receptors targeting sulfate anion will be prepared at the University of Kansas and the University of Texas, Austin. The receptor design will build on the substantial base of information our three groups have gathered during the last several years. The targeted receptors will thus contain aromatic or heterocyclic spacers and rely on various kinds of $\mathrm{NH}$ donor groups to effect anion recognition. 
Some will rely on mixed amine/amide (or amine/thioamide) recognition subunits, while others will be based solely on the use of pyrroles. Ease of synthesis will be a major consideration such that compound availability does not limit eventual application. However, the overriding factor will be to obtain systems that significantly advance the understanding of the fundamental determinants of anion recognition, not only in regard to binding (affinity, specificity) but also, necessarily, to extraction and stripping (efficacy, selectivity).

In light of such general considerations, the plan is to focus our attention on five specific principles that are considered highly relevant to the fundamental problem of understanding anion recognition:

1. Topological complementarity: By carefully crafting receptor design with hydrogen-bonding functionalities placed in ideal locations for interacting with the substrate, geometries that lead to optimized sulfate anion binding will be "mapped out."

2. Hydrogen-bonding ability (i.e., NH donor strength). By (1) varying the functional groups responsible for binding (e.g., amide, thioamide, and pyrrole), and (2) by adding electron-withdrawing groups at appropriate places in the receptor, the most effective NH binding subunits will be identified.

3. Preorganization vs. nonpreorganization: By examining the influence of other factors, such as size, shape, and the presence of internal hydrogen bonding units (e.g., pyridine) in promoting a preorganized cavity ready to accept the anion guest, a better understanding of the energetics of binding and the role preorganization plays in affinity can be gained.

4. Dimensionality: By exploring the differences between monocyclic, bicyclic, and polycyclic receptors, a better understanding of the influence of open (as in the monocycles) and enclosed environments (as in the cryptands) can be assessed.

5. Charge complementarity: By (1) exploring both neutral and positively charged (quaternized) analogs in extraction, (2) assessing the relative benefits of proton + sulfate anion co-extraction, and (3) examining crowncontaining systems, the questions of ion pair-based (dual-hosts or ditopic ion-pair receptor) co-extraction will be addressed.

Structural frameworks (from the Bowman-James and Sessler groups) that look the most promising (e.g., those displaying high selectivity and affinity for sulfate anion) are being examined as sulfate extractants in the Moyer lab. Neutral sulfate receptors will be tested either as synergists for anion exchange or in dual-host systems, and ditopic receptors will be examined alone. Systematic studies will examine the effect of solvent type on extraction efficacy and aqueous-compositional variables. The net result of this work is thus expected to be the development of robust, readily synthesized, and economically feasible systems that are highly selective for sulfate, and capable of functioning throughout a wide range of $\mathrm{pH}$. Such systems will serve as model prototypes setting the stage for potential follow-on proposals on process development work.

\section{Research Progress and Implications}

This report summarizes work performed in approximately the first year and a half of the current three-year renewal period. Work at ORNL during this time period focused on exploring the novel concept of synergized anion exchange, demonstrated for the first time in this project. Anion exchange has been selectively enhanced through the synergistic action of hydrogen-bonddonating anion receptors in combination with a traditional quaternary ammonium extractant. Synergized anion exchange represents a powerful way to control the selectivity of the classical technique of anion exchange. Previously, the selectivity of anion-exchange processes has been 
limited to a selectivity type that we have dubbed Hofmeister bias. A ubiquitous anion selectivity exhibited by most anion separation systems, Hofmeister bias implies a monotonic selectivity favoring large, charge-diffuse anions. Now it is possible with the synergistic anion exchange to employ selective anion receptors to control the overall exchange selectivity. It is also a new tool for rapidly assessing pair-wise anion selectivity by neutral anion receptors in a system readily adaptable to potential applications in analysis or process separations.

Specific results show that calixpyrroles (University of Texas, Austin) and tetraamide macrocycles (University of Kansas) shown in Figure 1 strongly enhance the extraction of sulfate

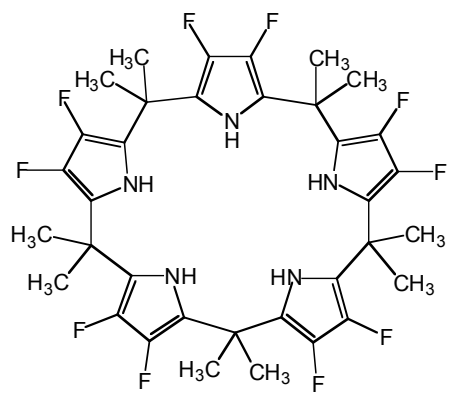

R1

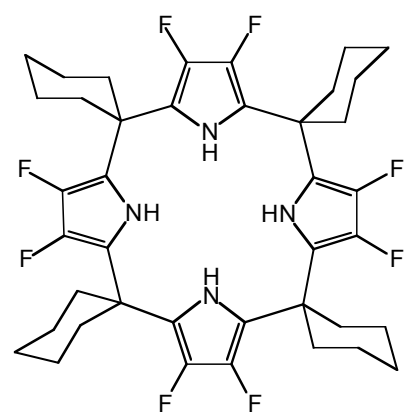

R4

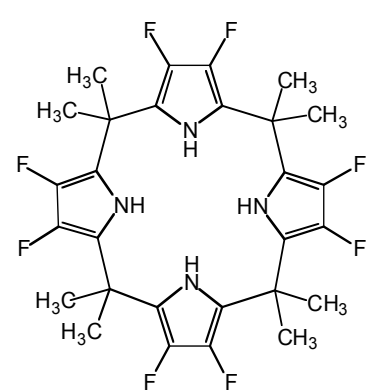

R2

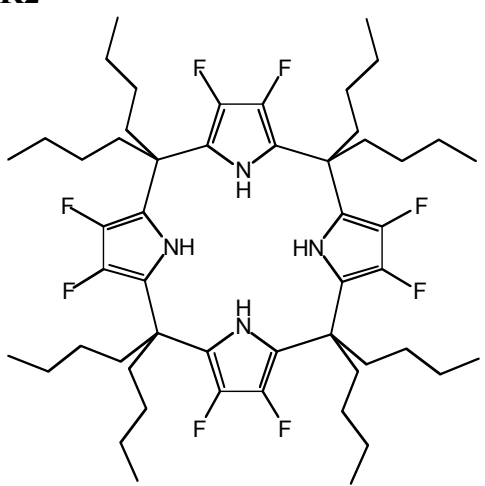

R5

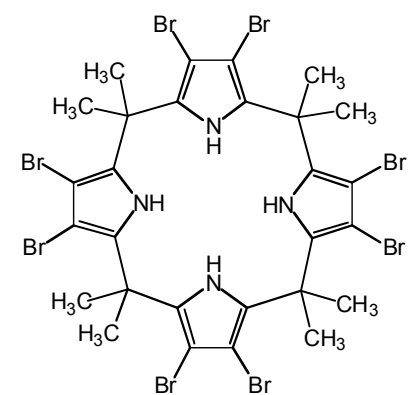

R3

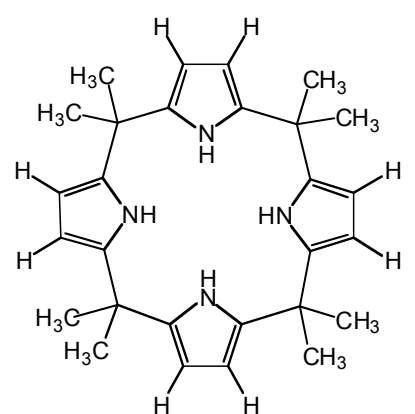

R6
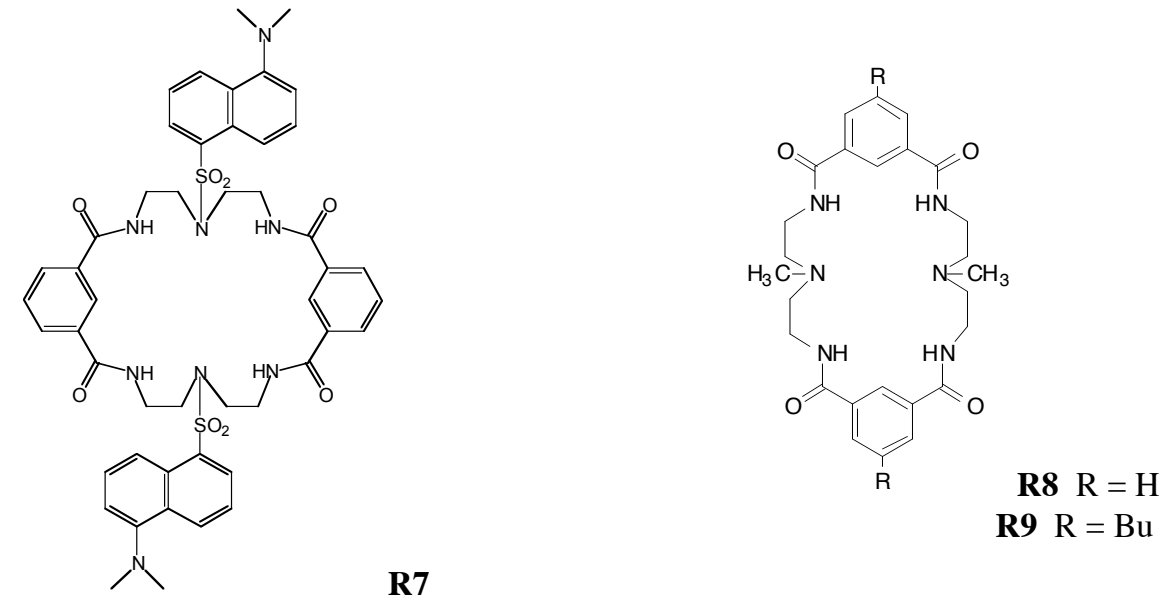

R7

Figure 1. Anion receptors used in this project. 
by tricaprylmethylammonium nitrate or chloride in the presence of excess nitrate and chloride. Survey results have been obtained for all of these compounds by measuring the sulfate distribution ratio with the aid of ${ }^{35} \mathrm{~S}$ tracer (a beta emitter). Typical results are shown in Figure 2, where it may be seen that increasing concentration of the anion receptors yields increasing sulfate extraction; $\mathbf{R 8}$ is an exception thought to have insufficient lipophilicity to stay in the organic phase. Enhancements of up to two orders of magnitude were obtained. These results represent a rare demonstration of the ability of anion receptors acting to overcome the Hofmeister bias in a competitive environment. A manuscript is in preparation.

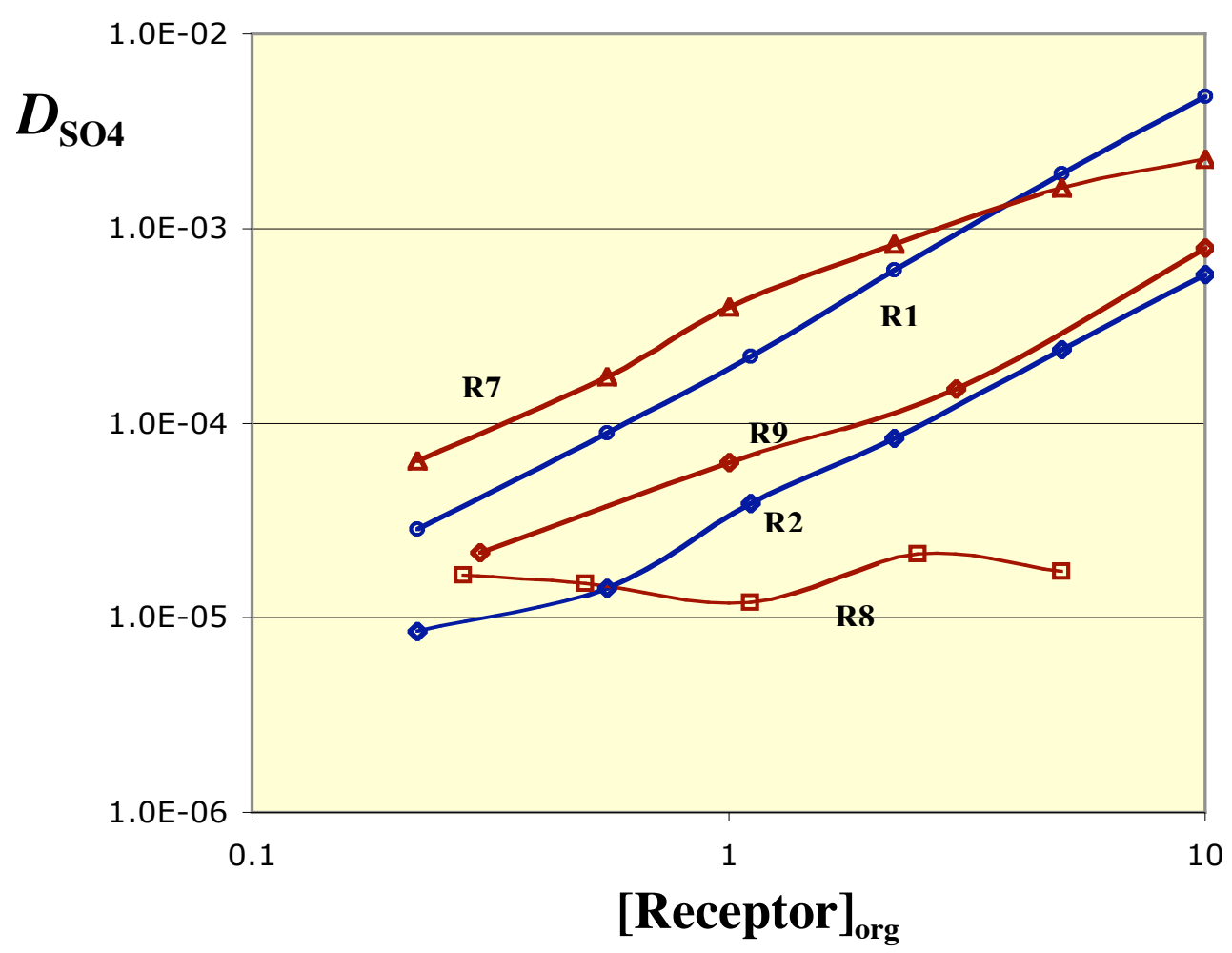

Figure 2. Extraction of sulfate from water using a chloroform solution containing $10 \mathrm{mM}$ tricaprylmethylammonium nitrate and varying concentration of two tetraamide macrocycles. Aqueous phase: $10 \mathrm{mM} \mathrm{NaNO}_{3}$ and $0.1 \mathrm{mM} \mathrm{Na}_{2} \mathrm{SO}_{4}$. Equal volumes of organic and aqueous phases were equilibrated for $1 \mathrm{~h}$ at $25^{\circ} \mathrm{C}$.

An equilibrium model has helped to rationalize the process of synergized anion exchange. Equilibria included in the model are shown in Table 1. The model is based on specific binding of the target anion by the anion receptor. 
Table 1. Equilibria associated with sulfate extraction.

\begin{tabular}{|c|l|}
\hline No. & Equation \\
\hline 1 & $\mathrm{Q}^{+}(\mathrm{aq})+\mathrm{X}^{-}(\mathrm{aq}) \rightleftharpoons K_{1} \rightleftarrows \mathrm{Q}^{+} \mathrm{X}^{-}(\mathrm{org})$ \\
\hline 2 & $2 \mathrm{Q}^{+}(\mathrm{aq})+\mathrm{Y}^{2-}(\mathrm{aq}) \rightleftharpoons K_{2} \rightleftarrows \mathrm{Q}_{2}{ }^{+} \mathrm{Y}^{2-}(\mathrm{org})$ \\
\hline 3 & $2 \mathrm{Q}^{+}(\mathrm{aq})+\mathrm{Y}^{2-}(\mathrm{aq})+\mathrm{R}(\mathrm{org}) \stackrel{K_{3}}{\rightleftharpoons} \mathrm{Q}_{2}{ }^{+} \mathrm{RY}^{2-}(\mathrm{org})$ \\
\hline 4 & $2 \mathrm{Q}^{+}(\mathrm{aq})+\mathrm{Y}^{2-}(\mathrm{aq})+2 \mathrm{R}(\mathrm{org}) \rightleftharpoons K_{4} \rightleftharpoons \mathrm{Q}_{2}{ }^{+} \mathrm{R}_{2} \mathrm{Y}^{2-}(\mathrm{org})$ \\
\hline
\end{tabular}

Progress has been made in understanding the behavior of anion receptors in so-called dual-host systems. In this approach, a metal salt is extracted by a synergistic combination of a cation receptor and an anion receptor. The binding of both ions by their respective receptors lends a double boost to the overall extraction strength in that two extra, favorable Gibbs energy terms are added to the thermodynamic driving force. Taking advantage of our work on cesium extraction in other projects, we have here used the extraction of cesium salts as a vehicle for understanding anion-binding by added anion receptors, including R7. A thermodynamic analysis of such systems revealed a way to compare the extraction of anions of multiple charge types. If the anion receptor has zero effect, then a plot of $[(z+1) / z] \log D_{\mathrm{Cs}}$ vs $\square G_{\mathrm{p}}{ }^{\circ} / z$ will be linear, where $z$ is the anion charge, $D_{\mathrm{Cs}}$ is the cesium distribution ratio (readily measurable using ${ }^{137} \mathrm{Cs}$ tracer), and $\square G_{\mathrm{p}}{ }^{\circ}$ is the standard Gibbs energy of partitioning of the anion. This linearity has been demonstrated in the absence of added receptor. One may see in Figure 3 that the addition of receptor $\mathbf{R} 7$ to a nitrobenzene solution containing $10 \mathrm{mM}$ calix[4]arenebis(tert-octylbenzocrown6) causes an increase in extraction above the line corresponding to no added receptor (solid line). The increase tends to be larger for the more charge-dense anions, like sulfate, that have high values of $\square G_{\mathrm{p}}{ }^{\circ}$. However, the effect is not uniform, as the anion receptor imposes its own selectivity. Sulfate may be seen to have the highest enhancement. The results show promise in pointing the way to sulfate selectivity. The results also show the viability of the dual-host approach, both as a way to effectively use anion receptors in liquid-liquid extraction and as a way to compare them systematically.

\section{Planned Activities}

In future efforts at ORNL, promising structural frameworks from the Bowman-James and Sessler groups will be examined as sulfate extractants. We expect these compounds to incorporate increased binding selectivity and affinity for sulfate. Increased solubility in organic solvents is also sought, as ultimately, practical systems will require receptors that can function at concentrations in the range $0.1-0.5 \mathrm{M}$. Studies seeking to quantify selectivity as it is influenced by solvation and anion-binding will be expanded at ORNL in liquid-liquid systems. These 


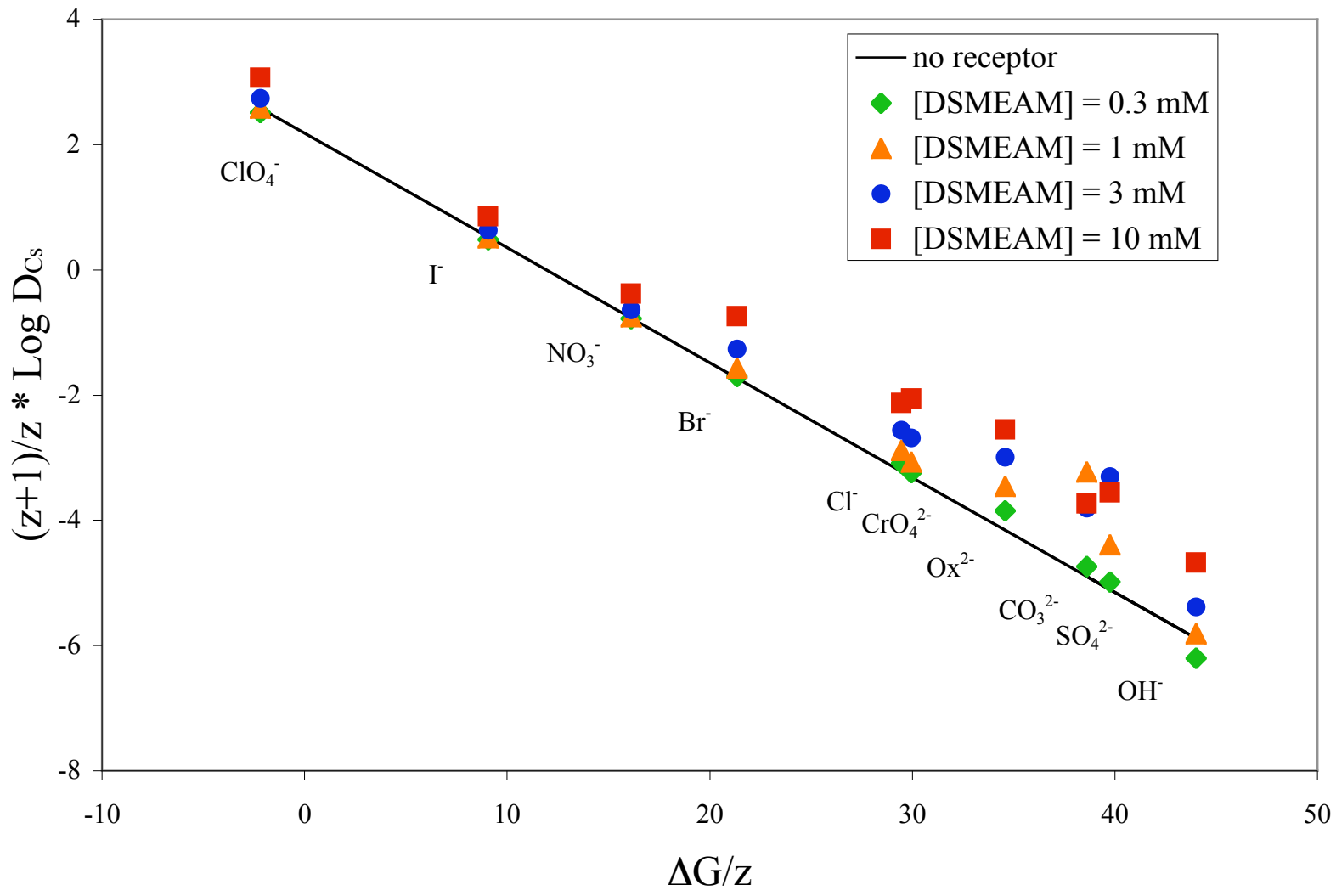

Figure 3. Extraction of 10 cesium salts by a dual-host system composed of $10 \mathrm{mM}$ calix[4]arenebis(tert-octylbenzocrown-6) and $0.3-10 \mathrm{mM}$ anion receptor R7 (DSMEAM) in nitrobenzene. The aqueous phase contained 0.001-1 M CsX plus $0.001 \mathrm{M} \mathrm{NaOH}$. O/A $=1 ; T=$ $25{ }^{\circ} \mathrm{C}$.

studies will be conducted with the primary goal to quantify anion selectivity. Studies will also begin to address the question of how to reverse the extraction process toward viable separation systems. Specifically, synergized anion exchange systems using appropriate lipophilic quaternary ammonium will be further explored, and two manuscripts will be submitted for publication based on the results. The thermodynamics of dual-host extraction will be refined, and a manuscript will be submitted for publication. Work will be initiated on characterizing extremely strong anion receptors based on an octapyrrole framework. Synthesis efforts in the Sessler group are aimed at overcoming the poor solubility of this class of macrocycles. Based on results reported by Sessler, these receptors promise unprecedented selectivity for sulfate.

\section{Information Access}

See also the www home page of the ORNL Chemical Separations Group: http://www.ornl.gov/csg. 


\section{Acknowledgments}

This research was sponsored by the Environmental Management Science Program of the Office of Science, U. S. Department of Energy, under a) contract no. DE-AC05-00OR22725 with Oak Ridge National Laboratory, managed and operated by UT-Battelle, LLC; Grant Nos. DE-FG-96ER62307 and DE-FG02-04ER63745 to the University of Kansas; and c) Grant DEFG02-04ER63741 to the University of Texas, Austin. Any opinions, findings, conclusions, or recommendations expressed herein are those of the authors and do not necessarily reflect the views of DOE. Any opinions, findings, conclusions, or recommendations expressed herein are those of the authors and do not necessarily reflect the views of DOE.

\section{Publications}

FY2003 - FY2004 Refereed Publications

Kavallieratos, K.; Bryan, J. C.; Sachleben, R. A.; Van Berkel, G. J.; Espetia, O. D.; Kelly, M. A.; Danby, A.; Bowman-James, K.; Moyer, B. A. Dual-Host Combinations: Using Tripodal Amides to Enhance Cesium Nitrate Extraction by Crown Ethers. In Fundamentals and Applications of Anion Separations; B. A. Moyer and R. P. Singh, Eds.; Kluwer Academic/Plenum: New York, 2004, pp 125-150.

Moyer, B. A.; Delmau, L. H.; Fowler, C. J.; Ruas, A.; Bostick, D. A.; Sessler, J. L.; Llinares, J. M.; Hossain, A.; Kang, S. O.; Bowman-James, K. Supramolecular Chemistry of Environmentally Relevant Anions., submitted.

FY2003 - FY2004 Other publications

Bowman-James, K.: Moyer, B. A.; Sessler, J. L. "Supramolecular Chemistry of Environmentally Relevant Anions," American Chemical Society National Meeting, New York, NY, Sept. 7-11, 2003.

Moyer, B. A.; Bonnesen, P. V.; Custelcean, R.; Delmau, L. H.; Haverlock, T. J.; Bostick, D. A.; Gorbunova, M.; Kang, H-A; Fowler, C. J.; Levitskaia, T. G.; Kavallieratos, K.; Ruas, A.; Hay, B. P.; Sessler, J. L.; Cho, W.-S.; Shriver, J. A.; Bowman-James, K.; Llinares, J. M.: Hossain, M. A. Using Coordination Chemistry to Selectively Separate Anions, From the Template Effect to Spontaneous Intermolecular Organization. A Celebration of Daryle Busch's first 50 years of Leadership, Teaching, Research and Service, $228^{\text {th }}$ ACS National Meeting, Philadelphia, PA, Aug. 22-16, 2004.

Moyer, B. A.; Kang, H.-A.; Fowler, C. J.; Levitskaia, T. G.; Delmau, L. H.; Ruas, A.; Bostick, D. A.; Haverlock, T. J.; Sessler, J. L.; Shriver, J. A.; Llinares, J. M.; Hossain, Md. A.; Bowman-James, K. Synergized Liquid-Liquid Anion Exchange: Use of Anion Receptors to Enhance the Extraction of Sulfate from a Nitrate Matrix by a Quaternary Ammonium Extractant. Chemistry Department Seminar, Univ. of Texas, Austin, Aug. 5, 2004.

Sessler, J. L.; Cho, W.-S.; Gross, D. E.;_Shriver, J. A.; Moyer, B. A.; Kang, H.-A.; Fowler, C. J.; Delmau, L. H.; Ruas, A.; Bostick, D. A.; Na, H.-K.; Lee, J.-S.; Lee, C.-H.; Marquez, M. Calixpyrrole Families: Synthesis, Characterization, and Anion Binding/Extraction Studies. $13^{\text {th }}$ International Symposium on Supramolecular Chemistry, Notre Dame, Indiana, July 25-30, 2004.

Moyer, B. A.; Fowler, C. J.; Delmau, L. H.; Ruas, A.; Bostick, D. A.; Sessler, J. L.; Shriver, J. A.; Llinares, J. M.; Hossain, Md. A.; Bowman-James, K. Synergized Liquid-Liquid Anion Exchange: Use of Anion Receptors to Enhance the Extraction of Sulfate from a Nitrate Matrix by a Quaternary Ammonium Extractant. 227th American Chemical Society National Meeting, Anaheim, CA, March 28-April 1, 2004.

Bowman-James, K.; Wilson, G. S.; Moyer, B. A. Supramolecular Chemistry of Selective Recognition for Anions of Environmental Relevance. Environmental Management Science Program Annual Report, Project \#74019; Oak Ridge National Laboratory: Oak Ridge, Tennessee, June 10, 2004; available on the World Wide Web site of the 
USDOE Environmental Management Science Program, URL $\underline{\text { http://emsp.em.doe.gov/portfolio/ProductDetails.asp?ProjectID=520 . }}$

Past Refereed Publications

Kavallieratos, K.; Danby, A. M.; Van Berkel, G. J.; Kelly, M. A.; Sachleben, R. A.; Moyer, B. A.; Bowman-James, K. Enhancement of $\mathrm{CsNO}_{3}$ Extraction in 1,2-Dichloroethane by Tris(2-aminoethyl)amine Triamide Derivatives via a Dual-Host Strategy. Anal. Chem. 2000, 72(21), 5258-5264.

Past Other publications

Kavallieratos, K., J.; Bryan, J. C.; Sachleben, R. A.; Van Berkel, G. J.; Kelly, M. A.; Bowman-James, K.; and Moyer, B. A.; "Dual-Host Combinations: From Enhancing Cesium Nitrate Extraction to Attenuating the Hofmeister Bias," Fundamentals and Applications of Anion Separations, ACS National Meeting, Chicago, IL, Aug. 26-30, 2001.

Kavallieratos, K.; Bryan, J. C.; Kelly, M. A., Van Berkel, G. J.; Sachleben, R. A.; Moyer, B. A.; Danby, A. M.; and Bowman-James, K., "Anion Hosts as Efficient Tools for Enhancing Ion-Pair Extraction," 219th National Meeting of the American Chemical Society, San Francisco, CA, Mar. 26-31, 2000 (Invited).

Kavallieratos, K.; Sachleben, R. A.; Bryan, J. C.; Van Berkel, G. J.; Moyer, B. A.; Danby, A. M.; and BowmanJames, K., "A Dual-Host Strategy in Ion-Pair Extraction - Tripodal Anion Hosts Enhance Cs Extraction by Crown Ethers," Southeast Regional American Chemical Society Meeting, Knoxville, TN, Oct. 17-20, 1999 (Invited).

Bowman-James, K.; Kuczera, K.; Wilson, G. S.; and Moyer, B. A., "Anion Recognition and Binding," DOE EMSP Scientific Workshop, Chicago, IL, July 27-July 30, 1998.

Bowman-James, K.; Wilson, G. S.; and Moyer, B. A., "Supramolecular Chemistry of Selective Anion Recognition for Anions of Environmental Relevance," Environmental Management Science Program Annual Progress Report, June 4, 2002; available on World Wide Web site of the USDOE Office of Environmental Management, URL http://emsp.em.doe.gov/portfolio/ProductDetails.asp?ProjectID=520 .

Bowman-James, K.; Wilson, G. S.; and Moyer, B. A., "Supramolecular Chemistry of Selective Anion Recognition for Anions of Environmental Relevance," Environmental Management Science Program Annual Progress Report, June 14, 2001; available on World Wide Web site of the USDOE Office of Environmental Management, URL http://emsp.em.doe.gov/portfolio/ProductDetails.asp?ProjectID=520 .

Bowman-James, K.; Wilson, G. S.; Kuczera, K.; and Moyer, B. A., "Supramolecular Chemistry for Selective Anion Recognition for Anions of Environmental Relevance," Environmental Management Science Program Fiscal Year 1996 Awards FY 2000 Project Summary, Apr. 25, 2000; available on World Wide Web site of the USDOE Office of Environmental Management, URL http://emsp.em.doe.gov/portfolio/ProductDetails.asp?ProjectID=520.

Bowman-James, K.; Wilson, G. S.; Kuczera, K.; and Moyer, B. A., "Supramolecular Chemistry for Selective Anion Recognition for Anions of Environmental Relevance," Environmental Management Science Program Fiscal Year 1996 Awards Annual Progress Report, June 15, 1999; available on World Wide Web site of the USDOE Office of $\quad$ Environmental M a n a e m e t, http://emsp.em.doe.gov/portfolio/ProductDetails.asp?ProjectID=520.

Bowman-James, K.; Wilson, G. S.; Kuczera, K.; and Moyer, B. A., "Anion Recognition and Binding," Proc. DOE EMSP Scientific Workshop, Chicago, IL, July 27 - July 30, 1998; available at World Wide Web site of the USDOE Office Of Environmental Management, URL http://emsp.em.doe.gov/portfolio/ProductDetails.asp?ProjectID=520.

Bowman-James, K.; Wilson, G. S.; Kuczera, K.; and Moyer, B. A., "Supramolecular Chemistry for Selective Anion Recognition for Anions of Environmental Relevance," Environmental Management Science Program Fiscal Year 1996 Awards Annual Progress Report, June 1, 1998; available at World Wide Web site of the USDOE Office of $\quad$ Environmental M a a g e m t, $\quad$ U R http://emsp.em.doe.gov/portfolio/ProductDetails.asp?ProjectID=520.

Bowman-James, K.; Wilson, G. S.; Kuczera, K.; and Moyer, B. A., "Supramolecular Chemistry for Selective Anion Recognition for Anions of Environmental Relevance," Environmental Management Science Program Fiscal 
Year 1996 Awards Annual Progress Report, Sept., 1997; available at the World Wide Web site of the USDOE O f f i c e of E n viro $n$ m e $\mathrm{t}$ a 1 $\mathrm{M}$ a $\mathrm{n}$ a $\mathrm{g}$ e $\mathrm{m}$ e $\mathrm{nt}$,

U R L http://emsp.em.doe.gov/portfolio/ProductDetails.asp?ProjectID=520. 